\title{
Spiritual and Moral Orientation of Students Having Different Axiological Personality Types
}

\author{
Bilan Marina Anatolyevna \\ Department of Psychological Sciences \\ Kemerovo State University \\ Kemerovo, Russia \\ lma_05-80@mail.ru
}

\author{
Grigoryeva Elena Vladimirovna \\ Department of Psychological Sciences \\ Kemerovo State University \\ Kemerovo, Russia \\ GEB9@yandex.ru
}

\author{
Khakimova Nurya Ravilievna \\ Department of Psychological Sciences \\ Kemerovo State University \\ Kemerovo, Russia, \\ khakimova@kemsu.ru
}

\begin{abstract}
Issues of moral and spiritual development of students' personality take an important place in Psychology. There is a widespread view, that contemporary young people do not spend enough time on personal development, and do not have a clear idea of basic moral and spiritual values a person should have. In this regard, the search for relevant methods of raising a new generation targets youngsters' system of values as well as a valid conception of moral and spiritual development. The purpose of the research work is to analyze the characteristic features of the system of values young people obtain. Students with different axiological personality types made up the focus group of the research. The leading method is interviewing, and it is realized by means of questionnaires, M. Rokeach method, and R. Inglkhart's method modified by M.S. Yanitskiy. The evidence received confirms the supposition that there are some peculiarities of spiritual and moral orientation among students with different axiological personality types. Similarities include a preference for universal values, while differences lie in the hierarchy and clear understanding of each value content. The research findings might be used in teaching college students, consulting students and teachers, as well as in delivering psychological assistance to parents and teachers as a kind of the problem of preventive actions. It's necessary to develop spiritual and moral orientation among young people taking into consideration personal values and characteristic features of each type of personality.
\end{abstract}

Keywords - students, personality, values, spiritual and moral orientation, axiological type of personality.

\section{INTRODUCTION}

The "multimoral" world of the postmodern epoch turns us objectively to spiritual and moral problems of a contemporary person. Thereby the lingering moral crisis in Russia presents a marker of anomy and a social transformation continuation of the last decades. We can see the moral degradation of Russian society at all social layers and in a great variety of forms, which appear when the ruling elite disregard moral values, when corruption increases, and when deviant behaviour and devaluation of moral standards among people become typical of the whole nation $[1,2]$. In this respect, the demand for studies of different aspects of the spiritual and moral life of Russian citizens is actualized with the purpose to advance the nation recovery [3]. Therefore, research into the spiritual and moral orientation of students is a burning issue of many research works carried out by many scholars.

\section{PROBLEM STATEMENT}

Value orientation forms a dynamic system, which M.S. Yanitskiy calls the most important psychological tool we can use to determine directions and ways in which selfdevelopment might be realized. The author describes a level model of the value system of personality and distinguishes three stages of value orientation - adaptation, socialization, individualization $[4,5]$. Other researchers also remark that value orientation in modern science is an actual criterion for personality type formalization including moral types [2]. Spiritual and moral orientation as an element of the value system and a type of personality is the most important regulator of behaviour and activity, in a situation when a person makes a decision or determines his/her life principles and attitudes in general, composing the vertical or the core of his/her own personality.

In psychological studies spirituality is determined as a necessary attribute a person should have to understand the universe and his/her inner personality; to recognize his/her life mission objectively. A person can find answers to eternal questions in spirituality, for example, what love, goodness, truth and purpose of his/her being are. The notion of spirituality is determined as an individual demonstration of two fundamental necessities in the structure of a personality: an individual necessity to understand the world around, and a social necessity to live and perform for the sake of other people. Spirituality lies in a personal choice and personal understanding that this or that action must be perfect not to benefit, but to follow the way which is correct. Thereby, some people consider spirituality as the basis for social morality, while others think about the principles of religious doctrines or about an individual attitude toward other people's freedom and safety and try not to cross the line and corrupt other people.

Morality lies beyond the narrow limits of society, and morality rates don't depend on standard regulations and provisions accepted by the society. The inner personal perceptions of what is fair and correct are taken for the basis. Standards and rules play the role of a ground where the hierarchy of spiritual and moral values grows. Spirituality is the highest level of cultural development, which characterizes a human condition. It includes an ability to follow the highest values of social public life. Spirituality gives way to love, conscience and sense of responsibility; to rights, legal consciousness and statehood; to art and artistic beauty, to praying and religion. According to Russian psychologists the 
main criteria of spirituality is the intentionality as an action from inside to outside, i.e. towards somebody or something; reflection over the main values of life; freedom as selfdetermination; creation; evolved conscience and responsibility.

\section{LITERATURE REVIEW}

Literature analysis reveals a burning interest in spirituality and morality issues among scientists. Authors speculate on different aspects of spirituality, including the issues of values young people obtain. F.G. Asadullina and D.V. Malugin, studying the aspects of moral choice, think that value orientation is the basis of this choice or its significant factor [6]. A.E. Vorobyova and A.B. Kuprejchenko state that values are the elements of moral self-determination, and study morality and moral attitudes of young people in connection with their gender, occupation, matrimonial status and parental experience [7]. According to long-term studies of the Russian society present-day moral portrait, based on analysis and generalization of empiric evidences, A.V. Yurevich distinguished the following peculiarities of moral characteristic features of Russian youngsters: contradictions in moral values, large individual diversity in connection with moral standards, moral relativism of young people, devaluation of moral standards and orientation [2]. The evidence of Russian psychologists confirms the pragmatic aspect of young people's perception of what is good or bad, wrong and right. N.A. Jouravleva emphasizes changes of accents in value comprehension from creative self- realization, self-esteem and ethical values to social responsibility, business success and economic values. Herewith N.A. Jouravleva makes the conclusion about the similarity of values among young people in different generations but accentuates contradictions caused by modern-day life circumstances. Besides, the author appeals to past-time methods our educators used to develop values with young people within the educational system [8]. A.V. Yurevich stresses the necessity to help young people to obtain moral values, including justice values and patriotic feelings with a priority given to ethics in business relations and mass media production [2].

Non-Russian researches study moral values at the angle of moral development (G. Lind, D. Phillips, St. Harding, P.M. King, M.J. Mayhew et al). Their research works are based on L. Kohlberg's theory of staged moral development. L. Kohlberg marked three stages of individual development: preconventional, conventional, and post-conventional stages, which come in a certain order or one after another and keep going from the beginning to the end of a person' life. Preparation for citizenship, citizen participation, character development, moral leadership and society devotion are the components of moral development [9].

Non-Russian researchers also write about the influence which education produces on students' moral development. Educational institutions supply students with resources to develop moral abilities. A. Tolkie and M. Nikolie [10] note, that some longitudinal study results prove the education influence on the level of students' moral assertions. Considering the stages of moral development, described in L. Kohlberg's theory, authors note that university education in Croatia brings a substantial contribution to the development of students' moral assertions. Kaili C. Zhang and Esther Dawen $\mathrm{Yu}$ explain that spiritual values are interconnected positively with inner purposes; development of spiritual values can favour personal prosperity and allow students to find the meaning and purpose of life [11].

One more important question in the non-Russian science is comprehension of spirituality and interconnection of spirituality and religious commitment. P. Gibbons [12] determines spirituality as a search for direction, common sense, inner completeness and connection with transcendental elements. The explanation of the connection between spirituality and religious commitment is polemic. R. Clemente, R. Michetelsen and P. Selver consider spiritual values through the prism of religious orientation. A. Mohamed and some of the above-mentioned researchers state that there is no significant difference between spirituality and religious commitment [13]. D. Elkins, L. Hedstrom, L. Hughes, J. Leaf and C. Saunders [14] state that the increasing number of people develop their spirituality outside traditional religion. The majority of respondents in E.P. Shafranske and H.N. Malony's research work said that traditional religion was not the main source of their spirituality. In our study, the comprehension of spirituality is not connected with religious commitment. The authors understand incarnation as a moral beginning, affirmance of the faith in the moral standards of a person (conscience, sense of responsibility, honour, and dignity) [15].

Making a conclusion, let's note the similarity of Russian and non-Russian researchers' scientific attitudes that moral and spiritual orientation is the most important regulator in the situations of life and professional self-determination. The value system is dynamic and is specified by both personal factors and outside circumstances - habitat conditions. Spiritual and moral values hierarchy is formed on the ground of public standards and rules on condition of personal inner acceptance. Despite the similarity of main values among young people of different generations, their contradictory character is specified due to social and political conditions and factors. Thus, the need for moral values remains actual among young people. The core social institutions responsible for value formation and spiritual and moral orientation alongside with family and religious institutions are thought to be educational institutions including colleges. In our opinion, the central idea for university education must be to develop moral qualities of students. The responsiveness of value system allows us to foresee and to take into consideration the peculiarities of the spiritual and moral orientation of students and their development in conditions of vocational training.

\section{RESEARCH OBJECTIVE}

The study was carried out with the purpose of reviewing the peculiarities of the spiritual and moral orientation of students having different axiological personality types.

\section{Objectives:}

1. To study the appropriate characteristics of the spiritual and moral orientation of students.

2. To examine the spiritual and moral orientation of students having different axiological personality types. 
3. To describe a general and a variative part of appropriate characteristics of spiritual and moral orientation for students having different axiological personality types.

The supposition that spiritual and moral orientation of students, having different axiological personality types, is quite specific was checked; these peculiarities are presented in shared preferring universal values but building different value hierarchies and realizing value content due to the individual context.

\section{MATERIALS AND METHODS}

The research was carried out in the spring of 2018 at Kemerovo State University. Eighty two students of three classical departments, aged 18-22, presented the sample group of the Institute of Social and Psychological Studies. The leading method was interviewing, realized by means of questions, M. Rokeach's method and R. Inglkhart's method modified by M.S. Yanitskiy.

The structure of questions included the following components: perception of spiritual and moral values, their differences, preferences and comprehension, socialdemographic characteristics of respondents and self-rating of their moral and spiritual development. The questions were open and close, some of them were supposed to be rated by a 10-point scale.

The value sphere of personality was analyzed through M. Rokeach's method of "Value orientation" modified by D.A. Leontiev and through R. Inglkhart's method modified by M.S. Yanitskiy [4]. The evidence was processed through the content-analysis and mathematical statistics.

The respondents were divided into groups due to the axiological personality type on the basis of R. Inglkhart's method modified by M.S. Yanitskiy. Thirty two percent of students were classified as an adapting type, reflecting the intention to reduce the alarm in connection with physical and economic stability; seventy percent of respondents were classified as a socializing type oriented to other people, social integration, and to the achievement of a definite social status; fifteen percent of students were classified as an individualizing type characterized by independent behaviour with orientation to development, self-actualization, freedom and tolerance. The rest thirty six per cent of respondents were classified as intermediate.

\section{RESULTS AND DISCUSSION}

Initially, the respondents enumerated spiritual and moral values whereas the number of values wasn't limited. The results received are recorded in Table I.

The study results allowed us to show both the common and the individual features characterizing these types. Respondents of all groups sorted out family, justice, love, honesty and respect to the spiritual and moral type of values. The value of family can be explained by age-specific requirements of respondents. Young people plan to start a family. A family is responsible for a definite way of life, a way of thinking and relations. According to N.A. Jouravleva's study, family, love, friends, financial wealth, job, career, and freedom are toppriority values.

TABLE I. CONTENT OF SPIRItual ANd Moral Values of Students

\begin{tabular}{|l|l|l|}
\hline \multicolumn{1}{|c|}{ Value type } & $\begin{array}{l}\text { Average number } \\
\text { of words }\end{array}$ & \multicolumn{1}{|c|}{ The most popular values } \\
\hline Adapting & 10.4 & $\begin{array}{l}\text { Family, justice, honesty (honour), } \\
\text { friendship, conscience, kindness, } \\
\text { love, faith, responsibility, dignity, } \\
\text { respect. }\end{array}$ \\
\hline Socializing & 8.79 & $\begin{array}{l}\text { Honesty, patriotism, family, } \\
\text { responsibility, faith in goodness, } \\
\text { respect, love, justice, a desire to } \\
\text { help other people. }\end{array}$ \\
\hline Individualizing & 9.6 & $\begin{array}{l}\text { Love, ethics, creativity, respect, } \\
\text { self-development, family, justice, } \\
\text { conscience, tolerance, honour } \\
\text { (honesty). }\end{array}$ \\
\hline Intermediate & 9.2 & $\begin{array}{l}\text { Family, justice, honesty (honour), } \\
\text { love, conscience, respect, } \\
\text { goodness, self-development, } \\
\text { friendship. }\end{array}$ \\
\hline
\end{tabular}

Three types of respondents, except for those who were determined as socializing, classified the value of conscience as a spiritual and moral one. The value of friendship was classified as a spiritual and moral value by adapting and intermediate type respondents, while self-development was referred to the above-mentioned value by individualizing and intermediate respondents. N.A. Jouravleva [8] confirmed that such spiritual and moral values as mutual help, sympathy and friendship are kept in mind as fundamental ones. The value of self-development for intermediate type respondents can be explained in the following way. According to Ericson's opinion, studying at a higher educational institution is "a legislatively mandated delay" in accepting the role of an adult person which is called "psycho-sociable moratorium" in the context of forming a value system [4]. Three types of respondents, except for the individualizing ones, are oriented to the values of faith in goodness and goodness.

A distinguishing feature for the adapting type of personality is characterized by such values as faith and dignity; for the socializing type, they are patriotism and desire to help people around; for the individualizing type - ethics, creativity and tolerance. We would like to pay attention to such values as patriotism, ethics and creativity. Patriotism appeals to bring up and develop an aspiration for high spiritual and moral ideals among people by means of active self-realization of each personality for the benefit of the country [8]. Ethics and creativity are referred to the top-level values in the moral development of a person. The above-mentioned distinguishing features confirm the description of axiological personality types suggested by M.S. Yanitskiy.

Hereinafter the respondents estimated the importance of listed spiritual and moral values using a 10-point scale. The values were divided by the importance rate for the adapting type in the following proportion: responsibility (8.7), conscience (8.5), goodness (8.5), justice (8.3), dignity (8.3), mutual help (8.2), honesty (8.2), duty (8.0), tolerance (7.2), faith in goodness (6.6), altruism (6.4), love for the country 
(5.3). For the socializing type: justice (9.3), honesty (9.1), conscience (9.0), responsibility (8.7), dignity (8.7), mutual help (8.0), duty (7.9), faith in goodness (7.5), tolerance (7.4), goodness (6.0), altruism (6.5), love for the country (6.5). For the individualizing type: justice (9.4), responsibility (9.3), honesty (8.9), conscience (8.9), dignity (8.6), mutual help (8.5), goodness (8.3), faith in goodness (7.7), tolerance (7.2), duty (7.0), altruism (6.5) and love for the country (4.6). For the intermediate type: responsibility (9.2), conscience (9.2), justice (8.9), mutual help (8.8), dignity (8.6), honesty (8.5), goodness (8.3), tolerance (7.8), altruism (7.4), duty (7.2), faith in goodness (7.2) and love for the country (6.3).

Analyzing the rate of the importance of spiritual and moral values, the statistic differences were observed between the individualizing and intermediate types in the aspect of love for the country. Thus, this value is of less importance among the individualizing type of respondents.

TABLE II. CONTENT Characteristics of Preferable SPIRItUAL AND MORAL VALUES OF STUDENTS HAVING DIFFERENT AXIOLOGICAL PERSONALITY TYPES

\begin{tabular}{|c|c|c|c|c|}
\hline Rank & Adapting type & $\begin{array}{c}\text { Socializing } \\
\text { type }\end{array}$ & $\begin{array}{c}\text { Individualizing } \\
\text { type }\end{array}$ & $\begin{array}{c}\text { Intermediate } \\
\text { type }\end{array}$ \\
\hline 1 & $\begin{array}{l}\text { Honesty is a } \\
\text { moral quality, } \\
\text { including } \\
\text { reliability to } \\
\text { fulfil } \\
\text { obligations, } \\
\text { principles, } \\
\text { verity, open } \\
\text { intentions, } \\
\text { sincerity to } \\
\text { oneself and } \\
\text { other people. }\end{array}$ & $\begin{array}{l}\text { Responsibility } \\
\text { is a moral } \\
\text { quality, which } \\
\text { means being } \\
\text { able to take } \\
\text { responsibility } \\
\text { for actions, } \\
\text { keeping a } \\
\text { promise, } \\
\text { committing any } \\
\text { actions, which a } \\
\text { person must } \\
\text { understand the } \\
\text { consequences. }\end{array}$ & $\begin{array}{l}\text { Justice is a value, } \\
\text { which helps to } \\
\text { solve difficulties } \\
\text { which happen in } \\
\text { human relations; } \\
\text { is not a synonym } \\
\text { for equality, as } \\
\text { each r person } \\
\text { needs rown } \\
\text { resources ro to } \\
\text { achieve the same } \\
\text { aim. } \\
\text { maintains thstice } \\
\text { availability of } \\
\text { these resources } \\
\text { to each person. }\end{array}$ & $\begin{array}{l}\text { Responsibility } \\
\text { assumes } \\
\text { understanding } \\
\text { the importance } \\
\text { rate of the } \\
\text { actions and } \\
\text { obligation to } \\
\text { fulfil them; } \\
\text { everything in } \\
\text { the world } \\
\text { imposes } \\
\text { obligations. }\end{array}$ \\
\hline 2 & $\begin{array}{l}\text { Responsibility } \\
\text { is an ability to } \\
\text { be responsible } \\
\text { for one's } \\
\text { activity, } \\
\text { readiness to be } \\
\text { responsible for } \\
\text { the actions to } \\
\text { oneself and } \\
\text { other people. }\end{array}$ & $\begin{array}{l}\text { Honesty is one } \\
\text { of the main } \\
\text { human virtues, } \\
\text { moral quality, a } \\
\text { person acts due } \\
\text { to moral } \\
\text { standards. }\end{array}$ & $\begin{array}{l}\text { Conscience is } \\
\text { control over } \\
\text { feelings, actions, } \\
\text { world outlook, } \\
\text { and regulator of } \\
\text { human actions. }\end{array}$ & \begin{tabular}{|l} 
Conscience \\
means \\
estimating \\
your own \\
actions in the \\
context of \\
inner settings, \\
noncontradicti \\
on to life \\
choice.
\end{tabular} \\
\hline 3 & $\begin{array}{l}\text { Goodness is an } \\
\text { ability to } \\
\text { support; } \\
\text { relation to other } \\
\text { people without } \\
\text { aggression, } \\
\text { envy and profit. } \\
\text { A person must } \\
\text { be kind (as } \\
\text { possible) } \\
\text { communicating } \\
\text { with others, to } \\
\text { be a happy } \\
\text { person means } \\
\text { to bring } \\
\text { goodness. }\end{array}$ & $\begin{array}{|lr|}\text { Justice } & \text { means: } \\
\text { each } & \text { must } \\
\text { what } & \text { het } \\
\text { dese } \\
\text { deserves } & \text { when } \\
\text { relations } & \text { are } \\
\text { valued } & \text { by } \\
\text { merits. } & \\
\end{array}$ & $\begin{array}{lrr}\text { Dignity } & \text { is } \\
\text { value that } & \text { makes } \\
\text { us people, a } \\
\text { person r must } \\
\text { never r rose } \\
\text { his/her } & \text { dignity } \\
\text { and never } & \text { forget } \\
\text { about } & \text { other } \\
\text { people's dignity. }\end{array}$ & $\begin{array}{l}\text { Justice means } \\
\text { the quality of } \\
\text { consequences } \\
\text { for } \\
\text { participants, } \\
\text { consequences } \\
\text { in a situation } \\
\text { which will be } \\
\text { relatively } \\
\text { equal. }\end{array}$ \\
\hline
\end{tabular}

The most important values, among all the abovementioned, were chosen by respondents. Honesty, responsibility and goodness are considered to be the most important for the adapting type. Responsibility, honesty and justice are considered to be the most important for the socializing type. The individualizing type chooses justice, conscience and dignity as the most important values. Responsibility, conscience and justice are of top-importance for the intermediate type. The difference in content characteristics of spiritual and moral orientation are presented in Table II.

The value "conscience" is versatile for the individualizing and intermediate types. One of the moral values is conscience. Conscience is the inner regulator of a person's behaviour which regulates individual responsibility for personal performance. Conscience is the indicator of a moral condition of any society. At the same time, the value of goodness is a moral value for the adapting type of respondents.

Then the subjective value of a person as a spiritual and moral human was studied. The adapting type has the highest rating of a personal spirituality (7.19), the lowest rating of a personal spirituality (5.42) belongs to the individualizing type of respondents. The evidence differs at the statistically significant level $(\mathrm{p}<0.05)$. The intermediate type has the highest rate of the own morality (8.0), though the individualizing type has the lowest rating of morality (6.67), that is also a statistically significant difference $(\mathrm{p}<0.05)$.

Later the interaction between spiritual and moral selfratings and the importance of spiritual and moral values was studied among the students of different axiological personality types. It's worth pointing out the most significant correlations. The adapting type links the self-rating of spirituality to such values as faith in goodness $(\mathrm{r}=0.40)$ and tolerance $(\mathrm{r}=0.54)$, and the self-rating of morality - to love for the country $(\mathrm{r}=0.51)$. The greatest number of spiritual and moral self-rating correlations with the importance of values is observed among respondents of the intermediate type. The self-rating of spirituality is connected with such values as goodness $(\mathrm{r}=0.43)$, honesty $(\mathrm{r}=0.44)$, conscience $(\mathrm{r}=0.46)$, love for the country $(\mathrm{r}=0.41)$, mutual help $(\mathrm{r}=0.8)$. The self-rating of morality is connected with the value honesty $(\mathrm{r}=0.39)$ and conscience $(\mathrm{r}=0.52)$. Having analyzed the content characteristics of spiritual and moral values and the greatest number of correlations, it is evident that the intermediate type includes the values of three types, in other words, it can be transformed in another axiological personality type. The type totally confirms the validity of the chosen Yanitsky's model. It should be pointed out that the socializing and individualizing types of respondents have no significant correlations between the selfrating indicators of spirituality and morality and the importance of spiritual and moral values.

Through the M. Rokeach's method, the preferable terminal and instrumental values were found out among the students of different axiological personality types.

Analyzing Table III and Table IV, we find out that the list of preferable values corresponds to the general axiological tendency of each respondent personality type, confirming the above-written results. The student moral orientation is reflected 
mostly in the preference of instrumental values as they reflect the ways of achieving values. Thus, the students of all four types are oriented to honesty and responsibility. There were no statistically significant differences in such values as honesty and responsibility, as well as in values close to moral ones and distinguished independently in the course of interviews.

TABLE III. The Preferable Terminal Values of Students of DIFFERENT AXIOLOGICAL PERSONALITY TYPES

\begin{tabular}{|l|l|l|l|l|}
\hline \multirow{2}{*}{ Status } & \multicolumn{2}{|c|}{ Adapting } & \multicolumn{2}{c|}{ Socializing } \\
\cline { 2 - 5 } & \multicolumn{1}{|c|}{ values } & $\boldsymbol{M}$ & \multicolumn{1}{c|}{ values } & $\boldsymbol{M}$ \\
\hline 1 & Health & 3.2 & Love & 5.1 \\
\hline 2 & $\begin{array}{l}\text { Happy } \\
\text { family life }\end{array}$ & 5.6 & Health & 5.3 \\
\hline \multirow{2}{*}{3} & $\begin{array}{l}\text { Financially } \\
\text { comfortable life }\end{array}$ & 5.7 & Happy family life & 5.4 \\
\hline 4 & Love & 5.8 & Good true friends & 5.6 \\
\hline 5 & Good true friend & 6.5 & Interesting job & 6.6 \\
\hline 6 & Self-assurance & 7.1 & Self-assurance & 7.6 \\
\hline \multirow{2}{*}{ Status } & \multicolumn{2}{|c|}{ Individualizing } & \multicolumn{2}{c|}{ Intermediate } \\
\cline { 2 - 5 } values & \multicolumn{1}{|c|}{$\boldsymbol{\text { values }}$} & $\boldsymbol{M}$ \\
\hline 1 & Active life & 6.0 & Love & 3.4 \\
\hline 2 & Freedom & 6.2 & Health & 5.0 \\
\hline 3 & Development & 6.8 & Happy family life & 6.3 \\
\hline 4 & Self-assurance & 6.9 & Self-assurance & 6.9 \\
\hline 5 & Experience & 7.4 & Active life & 7.5 \\
\hline 6 & Health & 8.3 & Development & 8.3 \\
\hline
\end{tabular}

TABLE IV. The Preferable Instrumental Values of Students of DIFFERENT AXIOLOGICAL PERSONALITY TYPES

\begin{tabular}{|l|l|l|l|l|}
\hline \multirow{2}{*}{ Status } & \multicolumn{2}{|c|}{ Adapting } & \multicolumn{2}{c|}{ Socializing } \\
\cline { 2 - 5 } & \multicolumn{1}{|c|}{ values } & $\boldsymbol{M}$ & \multicolumn{1}{c|}{ values } & $\boldsymbol{M}$ \\
\hline 1 & Manners & 5.0 & Manners & 4.1 \\
\hline 2 & Responsibility & 5.8 & Responsibility & 4.4 \\
\hline 3 & Honesty & 7.1 & Education & 5.9 \\
\hline 4 & Vitality & 7.5 & Honesty of duty & 6.6 \\
\hline \multirow{2}{*}{5} & $\begin{array}{l}\text { Accuracy and } \\
\text { neatness }\end{array}$ & 7.9 & $\begin{array}{l}\text { Sense of } \\
\text { performances }\end{array}$ \\
\hline 6 & Education & 8.3 & Broadmindedness & 9.0 \\
\hline \multirow{2}{*}{ Status } & \multicolumn{2}{|c|}{ Individualizing } & \multicolumn{2}{c|}{ Intermediate } \\
\cline { 2 - 5 } 1 & values & $\boldsymbol{M}$ & Manners & $\boldsymbol{M}$ \\
\hline 2 & Honesty & 5.5 & Responsibility & 5.3 \\
\hline 3 & Education & 6.0 & Honesty & 5.8 \\
\hline 4 & Responsibility & 7.6 & Education & 7.1 \\
\hline 5 & Self-control & 7.8 & Vitality & 7.3 \\
\hline 6 & Independence & 8.0 & Broadmindedness & 8.2 \\
\hline
\end{tabular}

Therefore, the results obtained through M. Rokeach's method confirm the difference between axiological personality types. The structure of preferable terminal and instrumental values corresponds to the characteristics of axiological personality types. The adapting type is oriented to the values of health and financial wealth, as the corresponding value system is formed by the psychological defence mechanism. The socializing type (oriented to the socially accepted standards) values family, job and friends. The individualizing type, characterized by independence of opinions, judgements and morality, prefers the values of self-development, freedom and active life. The intermediate type characterized by diffused value orientations includes the values of three types which can be thought of as the absence of a final decision in a axiological attitude.
The results obtained through R. Inglkhart's method totally correspond to N.A. Jouravleva and M.S. Yanitskiy's idea that young people within modern conditions are oriented to the values of financial stability, then to the values of socialization, and more seldom to the values of individualization. Herewith, the intermediate type is more frequent in our study in relation to the rest personality types. The results received clearly show that the higher development level of the value system the students have, the higher level of spiritual and moral value they choose. Thereby the self-rating of personal spirituality and morality is mentioned in inverse correlation, the higher development level one has, the more self-critical he is. Hence spiritual and moral orientation, as well as the value orientation of the groups under analysis, appeared to be different.

\section{CONCLUSIONS}

Studying the peculiarities of the spiritual and moral orientation of students allowed us to state the model of universal human values. It was found out that the spiritual and moral values of students are of a constructive character, the university students are mostly oriented to the values approved by the society. The difference of axiological personality types is shown, the hypothesis about the difference between content characteristics for spiritual and moral values is confirmed. The results received require further clarification and thorough interpretation to study the peculiarities of spiritual and moral orientation formed in relation to the student's age, specialization and the study year. It requires a more precise consideration of the detailed content of values chosen by students. The educational system is one of the possible resources to develop the spiritual and moral behaviour of young people. It's necessary to model spiritual and moral values in compliance with the revealed value orientation of each personality type. The majority of people of the intermediate type allows planning the educational work to form spiritual values. It is also possible to form spiritual and moral orientation of young people, taking into consideration the strategic tasks to develop the society and appealing to known personality values.

\section{REFERENCES}

[1] A.V. Yurevich, "The moral state of modern russian society", in Sociological Studies, vol. 10, pp. 70-79, 2009.

[2] A.V. Yurevich, "The state of morals in contemporary Russian society: An empirical estimate", in Voprosy psychologii, vol. 6, pp. 49-62, 2016.

[3] M.I. Volovikova, "Morality in modern Russia", in Psychological Journal, vol. 30 (4), pp. 95-97, 2009.

[4] M.S. Yanitskiy, "Value Dimension of the Mass Consciousness", Novosibirsk: Publishing House of SB RAS, 2012.

[5] M.S. Ivanov, A.V. Seryy, and M.S. Yanitskiy, "Mobility as strategy of providing personal security in postmodern society", in The European Proceedings of Social \& Behavioural Sciences, pp. 1187-1196, 2018.

[6] F.G. Asadullina, and D.V. Malugin, "Value orientations of men and women as moral choice's determinants", in Psychological Journal, 2008, vol. 29 (6), pp. 48-55.

[7] A.E. Vorobieva, and A.B. Kupreichenko, "Moral self-determination of young people from different socio-demographic groups", in Psychological Journal, vol. 32 (1), pp. 22-33, 2011.

[8] N.A. Jouravleva, "Dynamics of Youngsters' Orientation Toward MoralEthical Values Is Topical Problem of Modern-Day Russian Society", in Psychological Journal, vol. 34 (5), pp. 46-57, 2013. 
[9] P.M. King, and M.J. Mayhew, "Chapter 9. Theory and research on the development of moral reasoning among college students", in Smart, J.C. Higher Education: Handbook of Theory and Research, 2004, pp. 375440.

[10] A. Tokić, and M. Nikolić, "Moral Reasoning Among Croatian Students of Different Academic Orientations", in European Journal of Multidisciplinary Studies, vol. 6 (2), pp. 208-213, Sep.-Dec. 2017, DOI: http://dx.doi.org/10.26417/ejms.v6i2.p

[11] C.Z. Kaili, and Esther Dawen Yu, "Quest for a good life: Spiritual values, life goals, and college students", in Journal Asia-Pacific Psychiatry, vol. 6 (1), pp. 91-98, April 2012, DOI: https://doi.org/10.1111/j.1758-5872.2012.00183.x

[12] P. Gibbons, "Spirituality at work: Definitions, measures, assumptions, and validity claims", Proceedings of the Academy of Management, USA, 2000, pp. 111-131.
[13] A. Mohamed, A. Hassan, and J. Wisniesk, "Spirituality in the workplace: A literature review", in Global Competitiveness, Vol. 9 (1), pp. 644-651, 2001.

[14] D. Elkins, L. Hedstrom, L. Hughes, J. Leaf, and C. Saunders, "Toward a humanistic-phenomenological spirituality: Definition, description, and measurement", in Journal of Humanistic Psychology, vol. 28 (4), pp. 5$18,1988$.

[15] E.P. Shafranske, and H. N. Malony, "Religion and the clinical practice of psychology: A case for inclusion", in E.P. Shafranske (Ed.), Religion and the clinical practice of psychology, Washington DC, US: American Psychological Association, 1996. pp. 561-586, DOI: http://dx.doi.org/10.1037/10199-041. 